\title{
Diagnosis of Brucellosis
}

\author{
Fernando Padilla Poester ${ }^{*}, 1$ Klaus Nielsen ${ }^{2}$, Luis Ernesto Samartino ${ }^{3}$ and Wei Ling $\mathrm{Yu}^{2}$ \\ ${ }^{I}$ Brazilian Committee of the National Programme for the Control and Eradication of Brucellosis and Tuberculosis, \\ Brasilia, DF, 70043-900, Brazil \\ ${ }^{2}$ Animal Diseases Research Institute, Canadian Food Inspection Agency, 3851 Fallowfield Rd., Nepean, Ontario, K2H \\ $8 P 9$, Canada \\ ${ }^{3}$ Institute of Pathobiology, INTA, CICVyA, CC 25 (1712), Castelar, Buenos Aires, Argentina
}

\begin{abstract}
Brucellosis is an important zoonosis and a significant cause of reproductive losses in animals. Abortion, placentitis, epididymitis, and orchitis are the most common clinical manifestations in animals. In humans, brucellosis is a debilitating and chronic disease, which may affect a variety of organs. Clinical diagnosis of brucellosis is not easily achieved. Laboratory testing is therefore very important for a correct identification of the disease in humans and for the detection and confirmation in animals. Definitive diagnosis is normally done by isolation and identification of the causative agent. While definitive, isolation is time-consuming, must be performed by highly skilled personnel, and it is hazardous. For these reasons, serological tests are normally preferred. Brucellosis serology have advanced considerably in the last decades with very sensitive and specific new tests available. Modern genetic characterization of Brucellae using molecular DNA technology have been developed. Several PCR-based assays have been proposed, from the rapid recognition of genus to differential identification of species and strains. This review describes bacteriological, serological, and molecular methods used for the diagnosis of human and animal brucellosis.
\end{abstract}

Keywords: Brucellosis, diagnosis, bacteriology, serology, molecular methods.

\section{INTRODUCTION}

Brucellosis became a problem for the British garrison in Malta with substantial morbidity and mortality among the soldiers. Dr. David Bruce, a military medic, was sent to try to deal with the problem. He coordinated a team of scientific personnel which succeeded in 1887 in isolating Micrococcus melitensis as the causative agent from raw goat milk consumed by the military personnel $[1,2]$. This bacterium would later carry his name, Brucella melitensis as does the remainder of the genus. Other species of Brucella include $B$. abortus isolated by Bang in 1897 [3] and B. suis first described by Traum [4]. These 3 species are the most important in terms of public health and economics. There are several other species, including $B$. ovis, $B$. canis, $B$. neotomae, B. microti and at least 2 species, B. ceti and $B$. pinnipedialis which infect marine mammals but are potential human pathogens as well.

The main clinical signs of brucellosis are abortion, retained placenta, stillbirth, orchitis, arthritis in animals and undulant fever in humans. These signs are, however, common to several other diseases. The epidemiology of the herd, based on low fertility rates, may help, as well as the history of recent contact with infectious materials or contaminated food in humans. Presumptive diagnosis can be made by the use of several specific serological tests to

*Address correspondence to this author at the Venancio Aires 569/303, Porto Alegre, 90040-193, Brazil, Brazilian Committee of the National Programme for the Control and Eradication of Brucellosis and Tuberculosis, Brasilia, DF, 70043-900, Brazil; Tel: 513211 2858; Fax: 613226 3446;

E-mails: poesterf@terra.com.br, poesterf@plug-in.com.br
Brucella antibodies, but unequivocal diagnosis requires the bacteriological demonstration of the organism. Hence, the collection and shipment of appropriate samples to the laboratory have great importance.

The diagnosis of brucellosis is usually performed by a combination of methods. A definitive diagnostic technique is not available yet, in spite of being pursued for more than one century.

Brucella spp. are bacteria that affect particularly individuals consuming unpasteurized dairy products, abattoir workers, veterinarians, farmers and the disease is easily acquired by people involved mainly in laboratory routines. Any work with these bacteria should be done only under biosafety level 3 conditions. The organism may be recovered from a variety of materials, the placenta being the most infective and with the greatest concentration of the bacteria, followed by lymph nodes and milk in animals and from blood in humans. Most Brucella strains are slow growing organisms on primary isolations, some of them requiring serum enriched culture media and even experienced laboratories report only isolation rates between $20-50 \%$.

The identification of Brucella culture relies upon a great deal of phenotypic traits such as requirement for $\mathrm{CO}_{2}$, phage typing and metabolic tests, which among other problems involves time, biosafety, trained personnel and somewhat ambiguous results. To overcome some of these problems, efforts have been made on the development of molecular diagnostic assays based on the amplification of genomic targets through different polymerase chain reaction (PCR) approaches. 
Brucella species, except for B. ovis and B. canis, contain smooth lipopolysaccharide (SLPS) in their outer cell wall. Smooth lipopolysaccharide contains an immunodominant Opolysaccharide (OPS) which has been chemically defined as a homopolymer of 4,6-dideoxy-4-formamide-alpha-Dmannose linked via glycosidic linkages [5]. Brucella ovis and $B$. canis lack the OPS component and as a result, their outer surface contains only rough lipopolysaccharide (RLPS) and protein antigens [6]. Because all smooth species share common epitopes in the OPS, virtually all serological tests for antibody to these bacteria use B. abortus antigen [7] while RLPS is commonly used as the main antigen for detection of antibody to B. ovis and B. canis $[6,8]$. Because most serological tests use $B$. abortus SLPS antigen, these tests will be discussed with some reference to tests using protein antigens.

The antibody response to $B$. abortus in cattle has received most attention from the literature. For this reason and in general, this antibody response will be used as an example for the serological tests.

Antibody response to $B$. abortus infection in cattle consists of early IgM isotype production, appearing usually 5-15 days after exposure [9-11]. The IgM antibody response is followed very shortly by production of $\operatorname{IgG} 1$ isotype of antibody and subsequently by $\operatorname{IgG} 2$ and $\operatorname{IgA}$ [10-14]. Because of the early onset of $\operatorname{IgM}$ antibody production, theoretically it would be best to measure this isotype as an indicator of exposure, however, a number of other microorganisms contain antigens with epitopes similar to those of OPS and the main antibody response to these cross reacting antigens is $\operatorname{IgM}[15]$. Therefore, measurement of IgM antibody sometimes gives false positive reactions in serological tests leading to low assay specificity. Production of IgG2 and IgA isotypes occurs later in infection and as a result, measurement of these antibodies would generally lower assay sensitivity. Therefore, the most useful antibody measurement for serological tests for brucellosis is IgG1 [11, $14,16,17]$.

In addition to cross reactions, vaccinal antibodies sometimes cause diagnostic problems. Brucella abortus S19 [18] is a widely used vaccine. This organism is antigenically indistinguishable from pathogenic strains of $B$. abortus, however, administration of the vaccine to young animals, usually between 3 and 8 months of age, generally allows the antibody response to wane sufficiently to eliminate some diagnostic problems by the time animals reach sexual maturity and are tested for brucellosis [19]. However, some animals were found to have residual antibody leading to higher antibody levels in vaccinated animals. Development of improved serological tests, for example the competitive enzyme immunoassay and fluorescence polarization assay [20] and the development of a live vaccine which contains no OPS (B. abortus RB51 developed by Schurig) [21], have largely overcome most of these problems.

\section{BACTERIOLOGICAL METHODS}

The use of highly selective culture media and the development of equipments for maceration of tissues have made isolation of Brucella a more rewarding task. Specimens for culturing must be carefully collected and appropriately handled during transport.

\section{Collection of Specimens}

The materials of choice from animals include stomach contents, spleen and lung from aborted fetuses, placentomes, fetal membranes, vaginal swabs, milk, semen and arthritis or hygroma fluids from adult animals. From animal carcasses, the preferred tissues for culture are the mammary, medial and internal iliac, retropharyngeal, parotid and prescapular lymph nodes and spleen. All specimens must be packed separately and transported immediately to the laboratory cooled or preferably frozen in leak proof containers. For humans, blood for culture is the material of choice but specimens need to be obtained early in the disease.

\section{Stained Smears}

The organisms can be demonstrated through stained smears prepared from fetal membranes, fetal stomach contents, vaginal swabs, semen, etc. The most common methods in use are the modified Ziehl-Neelsen and the modified Köster [22]. Brucellae are coccobacilli or short rods, usually arranged singly but sometimes in pairs or small groups. They are not truly acid fast. However, they are resistant to decolorisation by weak acids, and stain red against a blue background. Care must be taken as Coxiella burnetii and Clamydophila abortus may superficially resemble Brucella [22].

\section{Culture Media}

There is a range of commercially available culture media for growing Brucella. The most common basal media in use are: Triptcase soy $\left(\mathrm{BBL}^{\circledR}\right)$, Bacto Tryptose $\left(\mathrm{Difco}^{\circledR}\right)$, Triptic soy $\left(\mathrm{Gibco}^{\circledR}\right)$, Tryptone soya $\left(\mathrm{Oxoid}^{\mathbb{R}}\right)$. The powder media can be used to prepare either broth or agar medium. For culturing blood and other body fluids, it is preferred to use broth or a biphasic medium (Castañeda), mainly because Brucella is often present in small numbers. For other specimens, solid media with $2.5 \%$ agar facilitate the recognition of colonies and discourage bacterial dissociation. Most Brucella strains, particularly B. abortus biovar 2 and $B$. ovis, grow better in media containing $5-10 \%$ of sterile (equine or bovine) serum free from Brucella antibodies.

Frequently, field samples are contaminated with other bacteria, thus, selective media should be used to avoid overgrowth by fast growing agents. Any basal media mentioned above with agar may be used to prepare selective media. The most widely selective media used are the Kuzdas and Morse [23] and the Farrell's medium [24]. The Kuzdas and Morse uses the following antibiotics and quantities per liter of basal medium: $100 \mathrm{mg}$ of cycloheximide (fungistat), 25,000 units of bacitracin (active against gram-positive bacteria) and 6,000 units of polymyxin B (active against gram-negative bacteria). The Farrell's medium is prepared by the addition of the followings antibiotics and quantities per liter of basal medium: bacitracin $(25 \mathrm{mg})$, polymyxin B sulphate (5mg), nalidixic acid (5mg), nystatin (100,000 units), vancomycin $(20 \mathrm{mg})$, natamycin $(50 \mathrm{mg})$. As Farrell's medium is rather inhibitory for some strains of $B$. abortus, $B$. melitensis, and $B$. ovis, a modified Thayer-Martin medium may be used together with Farrell's. This medium can be prepared with GC medium as basal medium supplemented with $1 \%$ hemoglobin and the following antibiotics per liter of medium: colistin methanesulphonate (7.5mg), 
vancomycin (3mg), nitrofurantoin (10mg), nystatin $(100,000$ units) and amphotericin B (2.5mg) [25].

\section{Culture of Specimens}

Blood and other fluids - selective media is not required for culturing blood and other body fluids if they are collected with aseptic precautions. The Castañeda two-phase system is the most convenient. It consists of a bottle which contains both solid and liquid medium with $1-2 \%$ sodium citrate in the liquid phase. An inoculum of $5-10 \mathrm{ml}$ is added to the bottle and incubated at $37^{\circ} \mathrm{C}$ in the upright position in a closed jar or incubator in $10 \%$ carbon dioxide $\left(\mathrm{CO}_{2}\right)$ atmosphere. If no colonies are observed on the surface of the agar, the bottle should be tilted every $24-48 \mathrm{~h}$ to allow the broth flow over the agar. Positive cultures may be evident within one or two weeks. However it is advisable not to discard cultures as negative until four to six weeks have elapsed. When colonies are present they should be subcultured for further examination and typing.

Hemoculture is the most practical and effective means of isolating $B$. canis from an infected dog, provided the animal had not received antibiotic therapy. Solid or liquid selective media used for the isolation of other brucellae are satisfactory for isolation of $B$. canis [8]. Blood (approximately $5 \mathrm{ml}$ ) should be collected in heparin or $1 \%$ sodium citrate (EDTA is inhibitory). After 5 to 7 days of incubation in $10 \mathrm{ml}$ tubes of liquid medium at $37^{\circ} \mathrm{C}$ without added $\mathrm{CO}_{2}$, broth is spread onto solid medium, incubated at $37^{\circ} \mathrm{C}$ without added $\mathrm{CO}_{2}$ and examined after 3 to 5 days for the presence of typical colonies. The isolation rate may be increased by freezing blood-broth mixture at $-70^{\circ} \mathrm{C}$ and rapidly thawing before inoculation onto solid medium. Colonies of $B$. canis present a rough morphology when examined by obliquely reflected light and when touched with an inoculating needle tend to stick to the needle [22].

Fetal stomach contents, semen, synovial fluids, etc. may be streaked directly on solid selective medium or added to biphasic medium.

Milk - one of the most important sources of human infection is unpasteurized dairy products. For isolation of Brucella from these sources solid media is preferred. For milk, samples collected from every quarter of the udder should be centrifuged $(6000 \mathrm{~g})$ for 15 minutes. The cream and deposit are mixed and streaked on selective medium as they are likely to be heavily contaminated. Dairy products, particularly cheese that are likely to contain few organisms, should be cultured on enriched media after being macerated in tissue grinder or a stomacher. The enriched medium is prepared by adding to the autoclaved based peptone medium $1.5 \%$ of agar, selective antibiotics, $5 \% \mathrm{v} / \mathrm{v}$ of sterile bovine or equine serum and $1 \% \mathrm{w} / \mathrm{v}$ of dextrose [22].

Tissues - samples should be removed aseptically with sterile instruments and after the removal of the fat, should be macerated using a tissue grinder or a stomacher in bags containing sample and sterile phosphate buffered saline (PBS). The material is then spread on the surface of solid selective medium with a swab-stick. If tissues cannot be obtained aseptically, searing its surfaces in a flame before culturing may help.
Animal inoculation - guinea-pigs are the animals of choice. On some occasions this practice may be justified, for instance when looking for Brucella in some cheeses or when antibiotics for selective media are not available. Nowadays, however, the use of animal inoculation is becoming a rare practice for humanitarian reasons.

Vaginal swabs - should be taken after parturition or abortion in goats, sheep or cows as they are excellent sources of bacteria and Brucella is frequently recovered. Swabs contained in transport medium are preferred. Spreading the swab directly on the surface of the selective medium originate a large number of colonies.

\section{Humans}

Although Brucella can be isolated from bone marrow, cerebrospinal fluid, wound, pus, etc., blood is the material most frequently used for bacteriological culture in humans. The biphasic method of Castañeda with both solid and liquid medium in the same container is the method of choice [26]. If taken with aseptic precautions, selective medium is not necessary. Air supplemented with $5 \% \mathrm{CO}_{2}$ during incubation is recommended. Most blood cultures are positive between 7-21 days of incubation and cultures should carry out for at least 45 days before rejected as negative for Brucella.

Molecular methods such as PCR-based assays are also available and are particularly useful in chronically infected patients where the yield of bacteria from blood cultures is usually low $[27,28]$.

\section{Marine Mammals}

There is no ideal tissue for the isolation of Brucella from marine mammals, unless gross lesions found in tissues, including the skin are detected. The recommended tissues for the recovery of Brucella are the spleen, the mammary gland, the mandibular, gastric, external and internal iliac and colorectal lymph nodes, the testes and blood [29].

Some marine mammal isolates grow poorly on Farrell's medium. Although most cetacean isolates become visible on Farrell's after four days of incubation, isolates from seals often grow very slowly and appear in 7 to 10 days, if they grow at all. Concurrent inoculation onto a nonselective medium such dextrose agar or blood agar is also suggested [30]. The recommended incubation conditions for all primary cultures are in $10 \% \mathrm{CO}_{2}$ atmosphere at $37^{\circ} \mathrm{C}$. Most cetacean isolates will grow in the absence of increased $\mathrm{CO}_{2}$, but most isolates from pinnipeds are capnophilic [26]. Isolates from marine mammals have the typical smooth colony appearance of the genus. Cetacean isolates can be distinguished from pinnipeds isolates by their $\mathrm{CO}_{2}$ requirements, their growth on Farrell's medium in primary cultures and their metabolic activity on D-galactose [31]. Genetic techniques can also be used to identify marine mammals isolates of Brucella [32].

\section{Identification and Typing}

After $48-72 \mathrm{~h}$ of incubation at $37^{\circ} \mathrm{C}$, Brucella colonies are 0.5 to $1.0 \mathrm{~mm}$ in diameter with a convex and circular outline. Smooth strains are transparent and pale yellow, resembling droplets of honey with a shiny surface when observed in transmitted light. Rough colonies are more opaque with a granular surface. Dissociation of Brucella can be detected by 
the emulsification of a colony in $0.1 \% \mathrm{w} / \mathrm{v}$ aqueous acriflavine [33]. Smooth colonies produce a yellow uniform suspension whereas rough colonies produce granular agglutinates. Colonial variation can be detected also by examining the plates under oblique light after staining the colonies with crystal violet [34]. Smooth colonies appear translucent and pale yellow and rough colonies are stained with red, purple or blue with opaque and granular appearance.

Colonial morphology, staining, slide agglutination with anti-Brucella serum (smooth or rough), urease, catalase and oxidase tests are the basis for a culture to be identified as belonging to the genus Brucella. This can be done by most routine bacteriology laboratories. Once a culture has been identified as Brucella, it is important to classify the species and the biovars. This further classification should be done in specialized or reference laboratories. These tests are cumbersome and include carbon dioxide requirement $\left(\mathrm{CO}_{2}\right)$, production of hydrogen sulphide $\left(\mathrm{H}_{2} \mathrm{~S}\right)$, dye sensitivity (thionin and basic fuchsin), phage lysis, agglutination with A, M or R specific antisera and in some cases it is necessary to use the oxidative metabolic method. This latter test is time consuming and hazardous to laboratory personnel. For these reasons it should be performed only by international reference laboratories.

In countries where live vaccines such $B$. abortus strain 19, RB51 or B. melitensis Rev. 1 are used, occasional isolations of these strains from milk or tissues need to be distinguished from wild strains biovar 1. Strain 19 does not require $\mathrm{CO}_{2}$ and although a fairly high mutation rate to tolerance to erythritol $(1 \mathrm{mg} / \mathrm{ml})$ is observed, most strains do not grow on media containing this sugar [35]. Strain 19 does not grow in presence of thionin blue $(2 \mu \mathrm{g} / \mathrm{ml})$ or penicillin $(5$ $\mathrm{IU} / \mathrm{ml}$ ) whereas field strains from biovar 1 do. Rev 1 strains grow on media containing streptomycin $(2.5 \mu \mathrm{g} / \mathrm{ml})$ but not on thionin $(20 \mu \mathrm{g} / \mathrm{ml})$, basic fuchsin $(20 \mu \mathrm{g} / \mathrm{ml})$ or penicillin (5 IU/ml). Field strains of $B$. melitensis biovar 1 grow on media containing thionin, basic fuchsin and penicillin but not on streptomycin [22].

The RB51 strain can be identified by several characteristics such as: rough morphology of the colonies when examined by obliquely reflected light, growth in the presence of rifampicin $(250 \mu \mathrm{g}$ per $\mathrm{ml}$ of medium) and inability to produce OPS demonstrated by reacting RB51 colonies with OPS-specific monoclonal antibodies, dot-blot or western blots assays [21, 36]. Strains 19 and RB51 may be identified using specific PCR assays [37].

The characteristics of Brucella cultures and typing tests are presented in Table $\mathbf{1}$.

Classical identification and typing of Brucella spp. into their respective species and biovars need not only be done by highly trained personnel but also large amounts of viable organisms are required to be present in tissues as well as level 3 facilities are needed to overcome the risk of producing laboratory-acquired infections.

\section{Molecular Methods}

The use of the Polymerase Chain Reaction (PCR) to identify Brucella DNA at genus, species and even biovar levels has becoming extended to improve diagnostic tests and a diversity of methods have been developed. Applications for PCR methods range from the diagnosis of the disease to characterization of field isolates for epidemiological purposes including taxonomics studies.

The first brucellosis PCR-based test was introduced in 1990 [39] and was targeted to a gene encoding a 43-KDa outer membrane protein from B. abortus strain 19. According to some authors, the exact protocol of this assay was patented and never published, limiting its application by other laboratories [40]. Genus-specific PCR assays targeted at Brucella BCSP31gene and 16S-23S rRNA operon were early designed to identify unique genetic loci that are highly conserved in Brucella and are useful tests for screening diagnosis in human brucellosis or contamination of food products at genus level [41]. Other target genes such as IS711 and per have also been used to identify Brucella at the genus level $[42,43]$.

The first species-specific multiplex PCR was called AMOS-PCR assay which is used to identify and differentiate B. abortus biovars 1, 2 and 4, B. melitensis, B. ovis and B. suis biovar 1, based on the polymorphism arising from species-specific localization of the insertion sequence IS711 in the Brucella chromosome [44]. An improvement of this technique was introduced by incorporating additional strainspecific primers into the primer mixture for identification of the vaccine strains $\mathrm{S} 19$ and RB51 [37]. A further modification of the assay called BaSS-PCR (Brucella abortus Strain Specific PCR assay) was developed to identify and distinguish field strains of B. abortus biovars 1 , 2 and 4 (the only biovars occurring in the United States) and to distinguish these from vaccine strains and other Brucella species from cattle [45]. A new primer was developed, which together with the IS711 AMOS primer produced a PCR to identify the isolates of biovars 3,5,6 and 9 of $B$. abortus [46].

Appropriate primers were arbitrarily designed to permit hybridization at random in the different Brucella genomes as determined by the Arbitrary Primed PCR (AP-PCR) or the Random Amplified Polymorphic DNA (RAPD-PCR) [47]. The problem with this test was the inter-laboratory reproducibility limiting widespread adoption.

In addition to the commonly used PCR assays, a new Multiplex-PCR assay was developed that specifically identified $B$. neotomae, $B$. pinnipedialis, B. ceti, and $B$. microti. Furthermore, it differentiated B. abortus biovars 1, 2, 4 from biovars 3, 5, 6, 9, as well as between B. suis biovar 1, biovars 3, 4, and biovars 2 and 5 [48]. A Bruce-ladder multiplex PCR assay was also developed for identification and differentiation of Brucella sp. and vaccine strains [49].

An interesting approach in molecular techniques is the typing of Brucella strains for epidemiologic investigations or tracing back strains to their origins. The strategy for the development of these tests is based on the observation that most organisms (prokaryotic and eukaryotic) contain strings of tandem repeat sequences classified as microsatellites and minisatellites distributed throughout their genomes that may affect protein expression. Tandem Repeat (TR) sequences are interesting class of markers, since multiple alleles can be present at a single locus, and size differences are easily achieved by electrophoresis [50]. Tandem repeated 
Table 1. Species and Biovar Differentiation of the Genus Brucella*

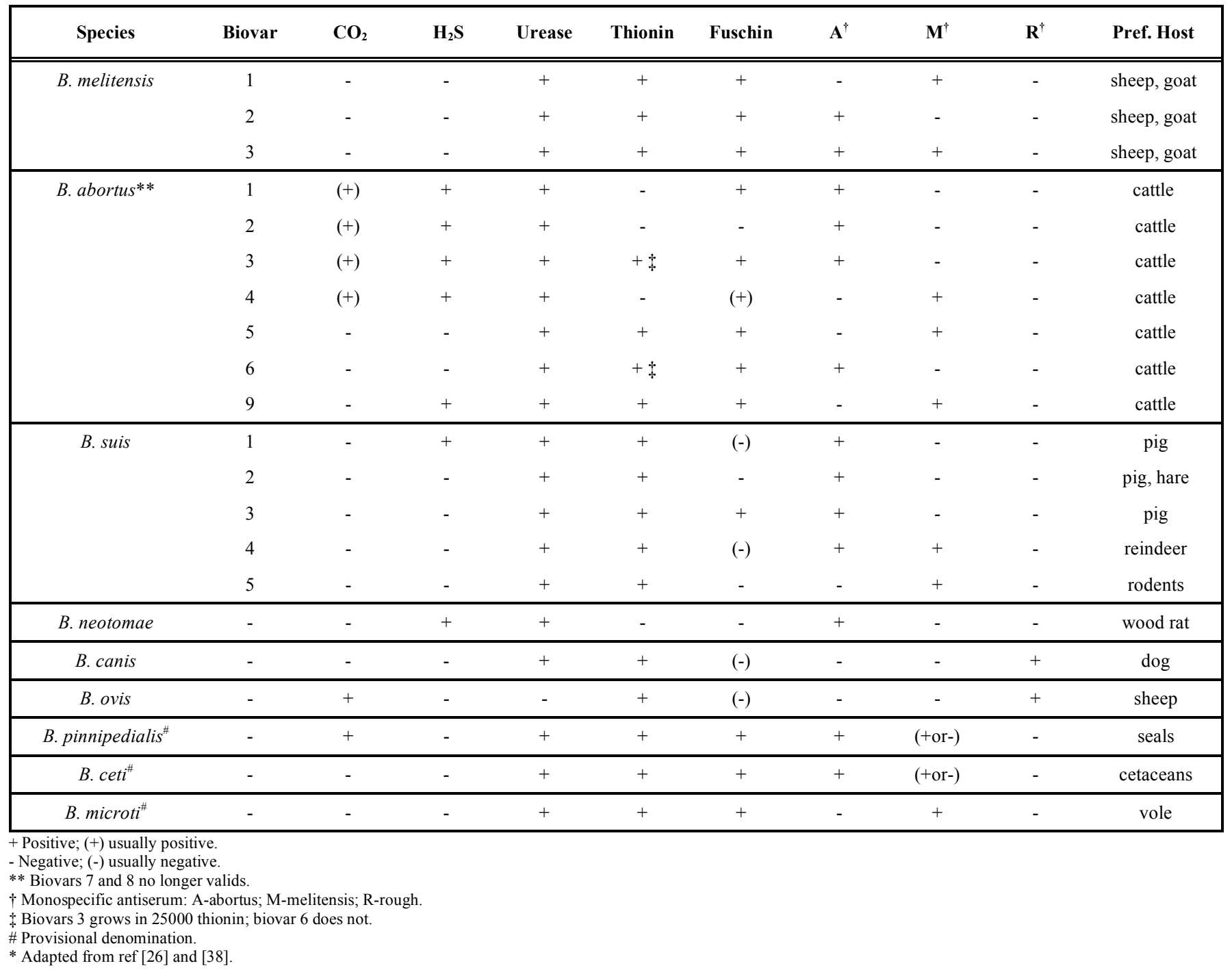

sequences located within a repeated sequence and present in multiple loci were recently described and used for Brucella strain typing. These methods based on multi-locus variable number of tandem repeats (MLVA) are powerful tools for epidemiological studies of closely related strains. Eight loci containing tandem repeats of 8-bp sequence gave rise to a PCR assay called Hoof-Prints (Hypervarible Octameric Oligonucleotide Finger-Prints) $[51,52]$. The assay is highly discriminating and very efficient in distinguishing strains within an outbreak but is unable to predict the biovar or the species of an isolate and for this reason cannot replace classical biotyping methods [50]. In addition, a new MLVA assay uses 15 markers consisting of two complementary panels, panel 1 ( 8 markers) and panel 2 (7 markers). The fifteen markers are a combination of moderate variable (minisatellite, panel 1) and highly discriminatory (microsatellite, panel 2) loci [50].

Recent improvements have made possible to amplify and detect DNA targets simultaneously through different RealTime PCR methods. The results are obtained almost instantly abbreviating the time of multiple tests [40].
The picture of PCR based tests is far from being complete and more research is needed in the molecular and sub-molecular ground to improve diagnostic of human and animal brucellosis.

\section{SEROLOGICAL METHODS}

Since the original recognition of the causative agent of brucellosis, Brucella sp., a large number of diagnostic schemes have been developed. The gold standard remains isolation and identification of the bacterium, however, for numerous reasons, alternative methods have been developed. The alternative methods include identification of nucleic acid from the bacterium by molecular biology technology and a large number of serological tests. Serological diagnosis is presumptive evidence of infection. There are considerable differences in the accuracy of the various serological tests and it is common to use a panel of tests and use the majority results as an indicator of exposure. Serological tests are generally divided into three areas: the classical or conventional tests, primary binding assays and developing technology. Each area will be reviewed, however, because of the volume of scientific literature, it is not possible to include all published information. 


\section{In-Use Serological Tests}

The first serological test for brucellosis was described by Wright and Smith in 1897 [53]. Since then a large number of tests and various modifications to enhance accuracy have been developed. The procedures are divided into two broad groups, the conventional tests and primary binding assays. Conventional tests all rely on the antibody being capable of performing a secondary function, for instance fixation of complement, while in primary binding assays the sole function of the antibody is to react with its antigen.

Because no serological test is $100 \%$ accurate, generally, diagnosis is made based on the results of two or more tests. Thus initial testing is commonly done using a screening test, a test with high sensitivity and perhaps of less specificity. The screening tests are usually relatively inexpensive, fast and simple to perform. If a positive reaction occurs in a screening test, a confirmatory test is performed. The confirmatory test is a test which provides good sensitivity but higher test specificity, thereby eliminating some false positive reactions. Most confirmatory tests are more complicated and more expensive to perform. Examples of screening tests are the acidified antigen tests and the indirect enzyme immunoassay and a confirmatory test is the competitive enzyme immunoassay.

\section{Conventional Tests}

\section{Agglutination tests:}

\subsection{Slow tests requiring incubation from 8 to 24 hours}

Standard tube (SAT)

SAT with added reducing agents such as 2-mercaptoethanol or dithiothreitol

SAT with addition of rivanol to precipitate glycoproteins

SAT with addition of ethylene diamine tetraacetic acid to reduce IgM binding (EDTA)

SAT with antiglobulin added to enhance agglutination

Milk ring test

\subsection{Rapid agglutination tests performed in minutes}

Rose Bengal

Modified Rose Bengal

Buffered antigen plate agglutination

Card

Antigen with rivanol added

Heat treatment of serum

Addition of $10 \%$ sodium chloride

\section{Complement fixation tests:}

Warm

Cold
Hemolysis in gel

Indirect hemolysis

\section{Precipitation tests}

Agar gel immunodiffusion

Radial immunodiffusion

\section{Primary Binding Assays}

Radioimmunoassay

Fluorescence immunoassay

Particle counting fluorescence immunoassay

Indirect enzyme immunoassay

Competitive enzyme immunoassay

Fluorescence polarization assay

There are variations on some of these tests and there are other tests not in common use which will be beyond the scope of this review. Each category of tests will be described and their performance will be discussed.

\section{Agglutination Tests}

The first description of a serological test for detection of antibody to Brucella sp. was published in 1897 [53]. A mixture of bacterial cell antigens was incubated with patient's serum in a glass tube and if a particular pattern of cell sediment was observed, it was considered as an indication of infection. This is basically the identical test still used in some countries, except that only B. abortus cells are used as the antigen. This test is performed at a near neutral $\mathrm{pH}$ and therefore detects IgM antibody very well and less so $\operatorname{IgG}$ resulting in low assay specificity $[12,14,54]$. As a result, the SAT while very sensitive is generally not used as a single test but rather in combination with other tests.

The specificity problems arising from the SAT led to a large number of modifications the goal of which was to prevent IgM from reacting with the antigen. The most common modifications were provision of an acid test environment, chemical reduction of IgM, precipitation of IgM and addition of EDTA. Other attempts were made to improve specificity, however, most were not commonly used and will not be discussed.

Agglutination tests generally cannot be used efficiently for the diagnosis of infection with $B$. ovis and $B$. canis, rough species of Brucella. As the whole cell antigens autoagglutinate, precipitins tests using soluble antigens are used instead.

\section{Acidified Antigen Modifications}

The most widely used tests employing acidified antigen are the Rose Bengal (RBT) [55] and the Buffered Antigen Plate Agglutination (BPAT) [56] tests. In these tests, $B$. abortus S99 or S1119.3 cells are stained with Rose Bengal (RBT) or Brilliant Green and Crystal Violet (BPAT), and suspended in a buffer which when mixed with the appropriate volume of serum results in a final $\mathrm{pH}$ of 3.65 . Appearance of agglutination must be within the specified 
time for each test ( 4 minutes for the RBT and 8 minutes for the BPAT). If incubated for longer periods, sometimes false reactions occur due to the formation of fibrin clots. This $\mathrm{pH}$ discourages agglutination by IgM but encourages agglutination by $\operatorname{IgG} 1$, generally reducing cross reactions $[11,12]$. False negative reactions occur in the acidified antigen tests, especially in the RBT, however, these tests are considered as suitable screening tests for brucellosis, followed by confirmatory testing. Antibody resulting from $B$. abortus $\mathrm{S} 19$ vaccination will react in these tests [7].

\section{Reducing Agents}

Dithiotreitol and 2-mercaptoethanol have both been used for the serological diagnosis of brucellosis [57, 58]. These reagents reduce disulfide bridges of $\operatorname{IgM}$ resulting in production of monomeric molecules with reduced ability to agglutinate. Either reducing agent may be added to serum as a diluent, using dilutions of 1:25 and increasing. For the diagnosis of brucellosis, reaction at a 1:25 serum dilution is considered positive. Some false negative reactions occur as some IgG molecules are also susceptible to reduction of disulfide bridges, rendering them unable to agglutinate, however, in general, reduction of $\operatorname{IgM}$ increases specificity. Care must be taken when using 2-mercaptoethanol as it is toxic and should only be used in a well ventilated area or a chemical hood. Test employing reducing agents are normally used as confirmatory tests, however, antibody resulting from B. abortus S19 vaccination may sometimes interfere [59].

\section{Precipitation}

Some non specific reactivity may be removed by precipitation of high molecular weight serum glycoproteins. This principle has been applied to serological diagnosis of brucellosis [59, 60]. This is commonly done by addition of rivanol (2-ethoxy-6,9-diaminoacridine lactate) to serum followed by removal of the precipitate by centrifugation and either a rapid plate type agglutination test with undiluted serum or a tube test using serum dilutions starting at 1:25. Because the protocol is fairly labour intensive, precipitation tests are generally used as confirmatory tests.

\section{Use of EDTA}

Because of the lack of specificity of the SAT, an adaptation of the test which includes the addition of ethylene diaminotetraacetic acid disodium salt has proven to significantly increase test specificity [61-63]. The mechanism by which EDTA reduces non specificity is not understood, however, it appears to eliminate attachment of immunoglobulins to the Brucella cell wall via the Fc piece. The modified SAT may be used in tubes or 96 well plates and incubation is usually overnight after which the cell sediment pattern is observed. The modified SAT has been used as a screening test.

\section{Milk Ring Test}

The agglutination test has been adapted to test milk for antibody to Brucella sp. [64, 65]. The format of this test is a little different in that hematoxylin stained Brucella cells are added to whole milk [60,64-66]. The reaction is allowed to take place. Immunoglobulins present in the milk will in part be attached to fat globules via the Fc portion of the molecule. If antibody to Brucella sp. is present, agglutination will take place resulting in a purple band at the top of the milk. If no antibody is present, the fat layer will remain a buff colour and the purple antigen will be distributed throughout the milk. This test may be applied to individual animals or to pooled milk samples using a larger volume of milk relative to the pool size [67]. The milk ring test is prone to false reactions caused by abnormal milk derived from mastitis, colostrums and milk from late in the lactation cycle $[65,68$, 69]. Still, in spite of its problems, it may be used as an inexpensive screening test in conjunction with other tests.

\section{Complement Fixation Tests}

In spite of the number of reagents required for the complement fixation test and its technical complications, it is a widely used confirmatory test for brucellosis. The basic test consists of $B$. abortus antigen, usually whole cells, incubated with dilutions of heat inactivated (to destroy indigenous complement) serum and a titrated source of complement, usually guinea pig serum. After a suitable time a pretitrated amount of sheep erythrocytes coated with rabbit antibody is added. If a primary immune complex (B. abortus cells and test serum) is formed due to the presence of certain antibody isotypes in the serum, complement was activated and therefore not available to react with the secondary immune complex of sheep erythrocytes and rabbit antibody, resulting in no or only slight lysis of the erythrocytes. Alternately, if no primary immune complex was formed, complement would cause all the sensitized sheep erythrocytes to lyse. Thus the amount of haemoglobin in solution is an inverse measure of anti-Brucella antibody activity. The complement fixation assay has been standardized [70, 71].

The complement fixation test is technically challenging because a large number of reagents must be titrated daily and a large number of controls of all the reagents is required. It is also an expensive test again because of the large number of reagents needed and because it is labour intensive. However, since only IgG1 isotype of antibody fixes complement well, the test specificity is high. Unfortunately the test does not allow for discrimination of B. abortus S19 derived antibody. Other problems include the subjectivity of the interpretation of results, occasional direct activation of complement by serum (anticomplementary activity) and the inability of the test for use with haemolysed serum samples. In spite of the shortcomings, the complement fixation test has been and is a valuable asset as a confirmatory test in control/eradication programs. There are a number of variations of the test, including the indirect haemolysis test [72-80], which are not widely used.

The complement fixation test using a hot saline extracted antigen preparation has been the most widely test used for the diagnosis of B. ovis infection in sheep [81-84]. However, the test has also some of the disadvantages presented for the diagnosis of bovine brucellosis such as complexity, necessity for serum heat inactivation, anticomplementary activity of some sera, difficulty in performing with hemolized sera and the the prozone phenomena [6].

\section{Precipitin Tests}

Precipitin tests were the first tests developed to distinguish $B$. abortus $\mathrm{S} 19$ vaccinal antibody from the 
antibody resulting from infection with pathogenic strains $[85,86]$. There are two basic formats, agar gel immunodiffusion in which test serum and soluble antigen are placed in adjacent wells 0.5 to $1.0 \mathrm{~cm}$ apart, cut in an agar matrix. After the reagents diffuse into the agar for a period of time, a visible precipitin band will form if the serum contains antibody. The second format involves incorporation of antigen into the agar matrix, placing test serum in a well in the agar and allowing the serum to diffuse radially, resulting in a precipitin ring if antibody is present in the serum. Both tests use OPS antigens derived from B. melitensis [85] or native hapten [86]. Both formats proved to be relatively insensitive with OPS antigen [87] while the sensitivity was better with native hapten antigen [88] and quite labour intensive but did provide results not available by any other test procedure at the time. Neither of the two formats of the precipitin tests is widely used.

Precipitin tests are widely used for the diagnosis of $B$. ovis infection in sheep using RLPS or hot saline extracted antigens and show similar sensitivity as compared to the complement fixation test [6].

\section{Primary Binding Assays}

\section{Indirect Formats}

Indirect primary binding assays usually rely on antibody present in test serum (or other body fluids) reacting with immobilized antigen and then being detected using a detection system with a marker molecule. The tracer system varies from antiglobulins labelled with isotopes [74-76, 78, 89-95] to fluorochromes [96-110] to enzymes (described initially by Carlsson et al., 1976 [111] and reviewed by Nielsen and Gall, 1994 [112-141].

The most commonly used system depends on enzymes for detection and consists of SLPS preparations passively attached to a polystyrene matrix usually in a 96 well format followed by addition of diluted serum or milk. The detection system varies but most often a monoclonal antibody specific for a heavy chain epitope of the test species and conjugated with horseradish peroxidase is used. Variation in the detection system includes the use of protein $A$, protein $G$, protein $\mathrm{A} / \mathrm{G}$ and polyclonal anti-immunoglobulin. Other enzyme such as alkaline phosphatase may be used as well. For peroxidase, the substrate is hydrogen peroxide but a number of different chromogens are available including ABTS and TMB. A multistep washing procedure is used between each stage of the assay.

A number of other antigens have been used, including RLPS, used mostly for the diagnosis of B. ovis and B. canis infection [84, 86, 142-154]. Numerous protein antigens have also been employed with variable success in indirect assays [155-165].

The indirect enzyme immunoassays generally have very high sensitivity but because they are largely unable to distinguish $B$. abortus S19 vaccinal antibody and cross reacting antibody, the specificity can be slightly lower than the assay specificity in areas where vaccination is not practiced. These assays are available as commercial kits from numerous sources and while there is some variation in their accuracy, the kits as well as individually developed assays are excellent screening assays for the diagnosis of brucellosis, especially in individual animal tests or serum or milk.

\section{Competitive Immunoassays}

There are two types of competitive assays used for brucellosis serology. In both cases, antigen is immobilized, a competing antibody, specific for OPS, with or without a detection system, is added at a predetermined dilution, followed by diluted test serum and in some cases by a separate detection system.

One assay type, the particle concentration fluorescent immunoassay has been widely used in the USA [166, 167]. It uses antigen coated polystyrene beads to which test serum and polyclonal Brucella specific antibody labelled with a fluorochrome is added. Excess reagents are removed with washing through a filter in the bottom of 96-well plates. The amount of fluorochrome labelled antibody attached to the beads is inversely related to the amount of antibody present in the serum. This assay can be automated.

A second and much more widely used competitive assay uses SLPS passively immobilized on the wall of 96 well polystyrene plates. Competition between a monoclonal antibody specific for a common epitope of OPS and test serum, both appropriately diluted are added. The monoclonal antibody may be labelled directly with enzyme or a secondary anti-mouse antibody labelled with enzyme may be added [124, 126, 168-193].

Competitive enzyme immunoassays were developed in order to overcome some of the problems arising from residual $B$. abortus $\mathrm{S} 19$ vaccinal antibody and from cross reacting antibody. By selecting a monoclonal antibody with slightly higher affinity for the antigen than most of the vaccinal/cross reacting antibody but with lower affinity than antibody arising from infection, reactivity by vaccinal antibody could be eliminated in the majority of cases. The specificity of the competitive enzyme immunoassay is very high, however, it is slightly less sensitive than the indirect enzyme immunoassay. This assay is an excellent confirmatory assay for the diagnosis of brucellosis in most mammalian species. Competitive assay kits are available commercially from various sources.

\section{Fluorescence Polarization Assay}

The basis for the fluorescence polarization assay is simple. The rate of rotation of a molecule in solution is inversely proportional to its size. A small molecule will rotate rapidly while larger molecules rotate more slowly. By attaching a fluorescing molecule to an antigen molecule, the rate of rotation can be measured using polarized light. The result is a measurement of the time it takes the molecule to rotate through a given angle. In the case of brucellosis serology, small molecular weight subunit of OPS is labelled with fluoroescein isothiocyanate and used as the antigen. When testing serum, blood or milk, if antibody to the OPS is present, the rate of rotation of the labelled antigen will be reduced. The rate of reduction is proportional to the amount of antibody present. The fluorescence polarization assay was developed in 1996 [194] but has since been validated [195213]. 
The fluorescence polarization assay is a homogeneous assay, requiring no washing steps or removal of unreacted components. It can be performed in a 96-well format or in a tube format. The tube format can be used in the field for rapid diagnosis. The serum or milk incubation time is a minimum of 2 minutes while the whole blood assay requires only 15 seconds of incubation. Because only 2 reagents, antigen and diluent buffer are required, the test is technically simple and relatively inexpensive. It does require a fluorescence polarization analyzer of which several are available at various costs. Diagnostic kits are also commercially available from several sources.

The fluorescence polarization assay is very accurate and the sensitivity:specificity can be manipulated by altering the cutoff value between positive and negative reactions to provide a very sensitive screening test as well as a highly specific confirmatory test. The FPA is capable of distinguishing vaccinal antibody in most vaccinated animals and it can eliminate some cross reactions as well.

Published sensitivity and specificity ranges for the commonly used serological tests are tabulated below. These are values obtained from the literature [20]. The Performance Index provides an overall estimate of the accuracy of the test by adding the sensitivity and specificity values. In Table $\mathbf{2}$, the Min and Max values represent the lowest and highest indexes.

Table 2. Sensitivity, Specificity and Performance Index of the Serological Tests for Brucellosis

\begin{tabular}{|c|c|c|c|}
\hline Test & \% Sensitivity & \% Specificity & $\begin{array}{c}\text { Performance Index } \\
\text { (Min - Max) }\end{array}$ \\
\hline \hline SAT & $29.1-100$ & $99.2-100$ & $128.3-200$ \\
\hline RBT & $21.0-98.3$ & $68.8-100$ & $89.8-198.3$ \\
\hline BPAT & $75.4-99.9$ & $90.6-100$ & $166.0-199.9$ \\
\hline RIV & $50.5-100$ & $21.9-100$ & $72.4-200$ \\
\hline 2ME & $56.2-100$ & $99.8-100$ & $156.0-200$ \\
\hline CFT & $23.0-97.0$ & $30.6-100$ & $53.6-197.0$ \\
\hline IELISA & $92.0-100$ & $90.6-100$ & $182.6-199.8$ \\
\hline CELISA & $97.5-100$ & $99.7-99.8$ & $197.3-199.8$ \\
\hline FPA & $99.0-99.3$ & $96.9-100$ & $195.9-199.3$ \\
\hline
\end{tabular}

\section{Other Tests}

Fluorescence immunoassay using a capture and elution technique to measure antibody eluted from antigen with cyanine-5 was developed by Silva et al. (2004) [214]. This versatile, portable assay gave good specificity and sensitivity values at a low cost.

Chemiluminescence assays have also been developed both in a homogeneous format $[193,215]$ and in a wash format [215]. The former used a competitive based assay in which two types of beads, a donor and an acceptor are pulled together by interaction of their conjugates. Using laser excitation, singlet oxygen is formed in a positive reaction resulting in conversion to light emission by the acceptor. This assay was shown to have a performance index comparable to other primary binding assays. The latter format included wash steps which apparently did not improve assay performance.

Lateral flow assays have also been developed. These assays utilized coloured beads conjugated with a detection reagent for antibody bound to an immobilized antigen on a cellulose membrane [216-219]. This type of assay has a definite advantage in that it requires no equipment for its performance, however, the interpretation is subjective, depending on the formation of a visible coloured line of reaction and the assay itself tends to be expensive because of the multiple ingredients included.

Finally, rapid slide agglutination tests have been developed for the serological diagnosis of $B$. canis infection [220-223] as well as a microagglutination test [224].

\section{False Positive Serological Reactors}

False positive results are a major problem which made serological diagnosis of brucellosis difficult in some cases. As described above, many modifications of various serological tests have been made to overcome the problem, some with limited success, some a little better. Virtually all serological tests for antibody to smooth Brucella sp. use LPS, part of LPS or whole cells as the antigen. The immunodominant epitope on the surface of the smooth cell is OPS the outermost portion of LPS. OPS is a homopolymer of 4-formamide-4,6-dideoxymannose. Most of the problems but not all arise from an immune response of the animal to another microorganism which shares epitopes with Brucella sp. OPS. The various cross reactions have been reviewed in considerable detail by Corbel [15].

Many serological tests cannot distinguish these antibody responses, however, because often the cross reacting antibody is of the IgM isotype, limiting the agglutinability of this antibody class somewhat diminishes the number of false positive reactors. Examples of IgM agglutination reduction include the use of dithiotreitol [225], 2-mercaptoethanol [58] and divalent cations [61].

A second line of reasoning has been to look for alternate antigens for serological tests. A number of protein antigens have been tried with limited success. For instance, Brucella Protein 26 (BP26) was cloned and the recombinant protein assessed for its value in the diagnosis of brucellosis. It was found to be of some potential using a western blotting method [226]. Further examination has demonstrated that while BP26 may be useful, it requires combination with other tests for accuracy [227-229]. Other candidate antigens include rough lipopolysaccharide (RLPS) part of which is unique to Brucella sp. This antigen which is very hydrophobic and difficult to prepare was shown to be capable of some discrimination of antibody due to Yersinia enterocolitica O:9 and other cross reacting microorganisms [174, 229-232]. Similarly, RLPS of Yersinia sp. was shown to eliminate Brucella cross reacting antibody in some cases [232].

Skin testing using a protein antigen derived from Brucella (Brucellergene, Brucellin or equivalent) is another approach to elimination of false reactions. While skin testing has certain logistical drawbacks, the test, in combination with serological tests can provide part of a sensitive and 
specific protocol for detection of infected animals, especially latently infected animals devoid of measurable antibody. It was shown to be able to eliminate most false positive serological reactors [233, 234], however, in a relatively recent review [235], both $B$. abortus vaccinated animals and animals infected with cross reacting microorganisms gave skin tests reactions for a period of time.

Another method of detection cell mediated immunity involves the measurement of cell proliferation or gamma interferon produced in response to antigenic stimulation of sensitized peripheral lymphocytes. Thus Brucella or Yersinia experimentally infected cattle could be clearly differentiated by either blastogenesis or skin testing while both gave measurable serological responses [236]. These results were disputed [237] using a Brucellergene gamma interferon production assay. In more recent studies, the gamma interferon test, also using Brucellergene as the lymphocyte stimulant, have been shown to discriminate $Y$. enterocolitica O:9 infection in pigs with high specificity compared to serological tests $[238,239]$.

\section{SUMMARY}

Diagnosis of brucellosis in any species is not a trivial matter. The only finite diagnosis is the recovery of the causative agent from the host. Because of inherent problems with bacterial isolation, inefficiency, cost, danger and other factors, most laboratories prefer to use other, more cost effective methods. Molecular biology as a diagnostic tool is advancing and will soon be at the point of replacing actual bacterial isolation. It is rapid, safe and cost effective, the only real problems being some uncertainties regarding specificity. Serological tests for the diagnosis of brucellosis have advanced considerably since their inception by Wright and Smith in 1897. The accuracy of modern assays has improved diagnosis resulting in more efficient control of the disease. However, the perfect test has still not been developed and may never be. In the meantime, the use of a vaccine that does not interfere with most serological tests and the validation and extensive use of primary binding assays has made diagnosis more manageable. Most likely the solution to the problems with accurate diagnosis will involve several tests for different functions of the immune response.

\section{REFERENCES}

[1] Bruce D. Note on the discovery of a microorganism in Malta fever. Practicioner 1887; 39: 161-70.

[2] Bruce D. Sur une nouvelle forme de fievre. Ann Inst Pasteur 1893; 4: 289-304.

[3] Bang B. Die Aetiologie des Seuchenhaften ('Infectiosen') Verwerfens. Zeit Tiermed 1897; 1: 241-78.

[4] Traum J. Report of the chief of the bureau of animal industry. USDA. Washington, DC. 1914; pp. 30-5.

[5] Bundle DR, Cherwonogrodzky J, Caroff M, et al. The lipopolysaccharides of Brucella abortus and B. melitensis. Ann Inst Pasteur Microbiol 1987; 138: 92-8.

[6] Blasco JM. In: Nielsen KH, Duncan JR, Eds. Brucella ovis. Boca Raton: CRC Press 1990; pp. 351-78.

[7] OIE, Bovine Brucellosis. In: Manual of Diagnostic Tests and Vaccines for Terrestrial Animals, CHAPTER 2.4.3. [on line] (2008) http://www.oie.int/fr/normes/mmanual/2008/pdf/2.04.03_B OVINE_BRUCELL.pdf [consulted 8 June 2009].

[8] Carmichael LE. In: Nielsen KH, Duncan JR, Eds. Brucella canis. Boca Raton: CRC Press 1990; pp. 335-50.

[9] Beh KJ. Distribution of Brucella antibody among immunoglobulin classes and a low molecular weight antibody fraction in serum and whey of cattle. Res Vet Sci 1973; 14: 381-4.
[10] Beh KJ. Quantitative distribution of Brucella antibody amongst immunoglobulin classes in vaccinated and infected cattle. Res Vet Sci 1974; 17: 1-4.

[11] Allan G, Chappel R, Williamson P, et al. A quantitative comparison of the sensitivity of serological tests for bovine brucellosis to different antibody classes. J Hyg 1976; 76: 287-98.

[12] Corbel MJ. Characterization of antibodies active in the Rose Bengal plate test for bovine brucellosis. Vet Rec 1972; 90: 484-5.

[13] Levieux D. Bovine immunoglobulins and brucellosis. 3. Activity of $\mathrm{IgG}_{1}, \mathrm{IgG}_{2}$ and IgM versus different batches of Rose Bengal antigen. Ann Rech Vet 1978; 9: 489-93.

[14] Nielsen K, Heck F, Wagner G, et al. Comparative assessment of antibody isotypes to Brucella abortus by primary and secondary binding assays. Prev Vet Med 1984; 2: 197-204.

[15] Corbel MJ. Recent advances in the study of Brucella antigens and their serological cross-reactions. Vet Bull 1985; 55: 927-42.

[16] Lamb V, Jones L, Schurig G, et al. Enzyme linked immunosorbent assay for bovine immunoglobulin subclass-specific response to Brucella abortus lipopolysaccharides. Infect Immun 1979; 26: 2407.

[17] Butler J, Seawright G, McGivern P, et al. Preliminary evidence for a diagnostic Immunoglobulin G1 antibody response among culturepositive cows vaccinated with Brucella abortus strain 19 and challenge exposed with strain 2308. Am J Vet Res 1986; 47: 125864.

[18] Buck JM. Studies of vaccination during calfhood to prevent bovine infectious abortion. J Agric Res 1930; 41: 667-85.

[19] Nicoletti P. In: Nielsen KH, Duncan JR, Eds. Vaccination. Boca Raton: CRC Press 1990; pp. 283-99.

[20] Nielsen K. Diagnosis of brucellosis by serology. Vet Microbiol 2002; 90: 447-59.

[21] Schurig GG, Roop RM, Buhrman D, et al. Biological properties of RB51; a stable rough strain of Brucella abortus. Vet Microbiol 1991; 28: 171-88.

[22] Alton GG, Jones LM, Angus RD, et al. Techniques for the brucellosis laboratory. Paris: Institut National de la Recherche Agronomique 1988.

[23] Kuzdas CD, Morse EV. A selective medium for the isolation of brucellae from contaminated materials. J Bacteriol 1953; 66: 502-4.

[24] Farrell ID. The development of new selective medium for the isolation of Brucella abortus from contaminated sources. Res Vet Sci 1974; 16: 280-6.

[25] Marin CM, Alabart JL, Blasco JM. Effect of antibiotics contained in two Brucella selective media on growth of B.abortus, B.melitensis and B.ovis. J Clin Microbiol 1996; 34: 426-8.

[26] Corbel MJ. Brucellosis in humans and animals. Geneva: WHO Press 2006.

[27] Morata P, Queipo-Ortuño MI, Reguera JM, et al. Diagnostic yield of a PCR-assay in focal complications of brucellosis. J Clin Microbiol 2001; 39: 3743-6.

[28] Colmenero JD, Queipo-Ortuño MI, Morata P. In: Lopez-Goñi I, Moriyón I, Eds. Polymerase chain reaction: a powerful new approach for the diagnosis of human brucellosis. Norfolk: Horizon Bioscience 2004; pp. 53-8.

[29] Foster G, MacMillan AP, Godfroid J, et al. A review of Brucella sp. infection of sea mammals with particular emphasis on isolates from Scotland. Vet Microbiol 2002; 90: 563-80.

[30] Forbes LB, Nielsen O, Measures L, et al. Brucellosis in ringed seals and harp seals from Canada. J Wildl Dis 2000; 36: 595-8.

[31] Foster G, Jahans KL, Reid RJ. Isolation of Brucella species from cetaceans seals and an otter. Vet Rec 1996; 138: 583-6.

[32] Cloeckaert A, Verger JM, Grayon M, et al. Classification of Brucella spp. isolated from marine mammals by DNA polymorphism at the omp2 locus. Microbes Infect 2001; 3: 729-38.

[33] Braun W, Bonestell AE. Independent variations of characteristics in Brucella abortus variants and their detection. Am J Vet Res 1947; 8: 386-90.

[34] White PG, Wilson JB. Differentiation of smooth and non-smooth colonies of brucellae. J Bacteriol 1951; 61: 239-40.

[35] Corner LA, Alton GG. Persistence of Brucella abortus strain 19 infection of adult cattle vaccinated with reduced doses. Res Vet Sci 1981; 31:342-4.

[36] Roop RM, Preston DM, Bagchi T, et al. Rapid identification of smooth Brucella species with monoclonal antibody. J Clin Microbiol 1987; 25: 2090-3. 
[37] Bricker BJ, Halling SM. Enhancement of the Brucella AMOS-PCR assay for differentiation of Brucella abortus vaccine strains S19 and RB51. J Clin Microbiol 1995; 33: 1640-2.

[38] Hubalek Z, Scholz HC, Sedlacek I, et al. Brucellosis of the Common Vole (Microtus arvalis). Vector Borne Zoo Dis 2007; 7: 679-87.

[39] Fekete A, Bantle JA, Halling SM, et al. Preliminary development of a diagnostic test for Brucella using polymerase chain reaction. J Appl Bacteriol 1990; 69: 216-27.

[40] Bricker BJ. In: Lopez-Goni I, Moryion I, Eds. Molecular diagnostic of animal brucellosis: a review of PCR-based assays and approaches. Norfolk: Horizon Bioscience 2004; pp. 25-51.

[41] Bricker BJ. PCR as a diagnostic tool for brucellosis. Vet Microbiol 2002; 90: 435-46.

[42] Halling SM, Tatum FM, Bricker BJ. Sequence and characterization of an insertion sequence, IS711, from Brucella ovis. Gene 1993; 133: $123-7$.

[43] Lubeck PS, Skurnik M, Ahrens P, et al. A multiplex PCR-detection assay for Yersinia enterocolitica serotype O:9 and Brucella spp. based on the perosamine synthetase gene. Application to Brucella diagnostics. Adv Exp Med Biol 2003; 529: 451-3.

[44] Bricker BJ, Halling SM. Differentiation of Brucella abortus bv 1, 2, and 4, Brucella melitensis, Brucella ovis, and Brucella suis bv 1 by PCR. J Clin Microbiol 1994; 32: 2660-6.

[45] Bricker BJ, Ewalt DR, Olsen SC, et al. Evaluation of the Brucella abortus species-specific polymerase chain reaction, an improved version of the Brucella AMOS polymerase chain reaction assay for cattle. J Vet Diagn Invest 2003; 15: 374-8.

[46] Ocampo-Sosa AA, Aguero-Balbin J, Garcia-Lobo JM. Development of a new PCR assay to identify Brucella abortus biovars 5, 6 and 9 and the new subgroup $3 \mathrm{~b}$ of biovar 3 . Vet Microbiol 2005; 110: 41-51.

[47] Fekete A, Bantle JA, Halling SM, et al. Amplification fragment length polymorphism in Brucella strains by use of polymerase chain reaction with arbitrary primers. J Bacteriol 1992; 174: 777883.

[48] Huber B, Scholz HC, Lucero N, et al. Development of a PCR assay for typing and subtyping of Brucella species. Int J Biol Sci 2009; 299: $563-73$

[49] Lopez-Goni I, Garcia-Yoldi D, Marin CM, et al. Evaluation of a multiplex PCR assay (bruce-ladder) for molecular typing of all Brucella species, including the vaccine strains. J Clin Microbiol 2008; 46: 3484-7.

[50] Le Fleche P, Jacques I, Grayon M, et al. Evaluation and selection of tandem repeat loci for Brucella MLVA typing assay. BMC Microbiol 2006; 6: 9.

[51] Bricker BJ, Ewalt DR, Halling SM. Brucella "Hoof-Prints": strain typing by multi-locus analysis of variable number tandem repeats (VNTRs). BMC Microbiol 2003; 3: 15.

[52] Bricker BJ, Ewalt DR. Evaluation of the Hoof-Print assay for typing Brucella abortus strains isolated from cattle in the United States: results with four performance criteria. BMC Microbiol 2005; 5: 37.

[53] Wright AE, Smith F. On the application of the serum test to the differential diagnosis of typhoid and Malta fever. Lancet 1887; 1 : 656-9.

[54] Rice C, Boyes B. Serum immunoglobulins in bovine brucellosis. N Z Vet J 1971; 19: 146-54.

[55] Morgan W, MacKinnon D, Lawson J, et al. The rose Bengal plate agglutination test in the diagnosis of brucellosis. Vet Rec 1969; 85: 636-7.

[56] Angus R, Barton C. The production and evaluation of a buffered plate antigen for use in the presumptive test for brucellosis. Dev Biol Stand 1984; 56: 349-58.

[57] Klein G, Behan K. Determination of Brucella immunoglobulin G agglutinating antibody titer with dithiothreitol. J Clin Microbiol 1981; 14: 24-5.

[58] Rose J, Roepke M. Physicochemical properties of nonspecific bovine seroagglutinins for Brucella abortus. Am J Vet Res 1964; 25: $325-8$.

[59] Nicoletti P. Further evaluation of serologic procedures used to diagnose brucellosis. Am J Vet Res 1969; 30: 1811-21.

[60] Huber J, Nicoletti P. Comparison of the results of card, rivanol, complement fixation and milk ring test with the isolation rate of Brucella abortus from cattle. Am J Vet Res 1986; 47: 1529-31.
[61] Nielsen K, Samagh B, Speckman G, et al. The bovine immune response to Brucella abortus. Elimination of some sporadic serological reactions by chelation of divalent cations. Can J Comp Med 1979; 43: 420-5.

[62] Garin B, Trapp D, Gaumont R. Assessment of the EDTA seroagglutination test for the diagnosis of bovine brucellosis. Vet Rec 1985; 117: 444-5.

[63] MacMillan A, Cockrem D. Reduction of non-specific reactions to Brucella abortus serum agglutination test $\mathrm{y}$ the addition of EDTA. Res Vet Sci 1985; 38: 288-91.

[64] Hunter D, Allan J. An evaluation of milk and blood tests used to diagnose brucellosis. Vet Rec 1972; 88: 310-2.

[65] McCaughey WJ. Brucella milk ring tests on churn samples: a threeyear study. Vet Rec 1972; 90: 6-10.

[66] Sutra L, Caffin J, Dubray G. Role of immunoglobulins in the Brucella milk ring test. Vet Microbiol 1986; 12: 359-66.

[67] MacMillan AP. In: Nielsen KH, Duncan JR, Eds. Conventional serological tests, Boca Raton: CRC Press 1990; pp. 153-97.

[68] Kerr WR, Pearson KL, Rankin EF. The bovine udder and its agglutinins. Br Vet J 1959; 115: 105-9.

[69] Cunningham B. Vaccination of cattle with killed 45-20 adjuvant vaccine. Effects on serological and milk ring tests when used in cattle previously exposed to infection or vaccinated with S19. Vet Rec 1970; 86: 2-7.

[70] Hill W. Standardization of the complement fixation test for brucellosis. Bull OIE 1963; 60: 401-10.

[71] MacKinnon D. The complement fixation test in brucellosis. Bull OIE 1963; 60: 383-400.

[72] Plackett P, Cottew G, Best S. An indirect haemolysis test (IHLT) for bovine brucellosis. Aust Vet J 1976; 52: 136-40.

[73] Nicoletti P, Carlsen WB. Indirect hemolysis test in the serodiagnosis of bovine brucellosis. Am J Vet Res 1981; 42: 1494 7 .

[74] Tedder T, Hoffmann E. Immunoradiometric assay for examination and quantitation of Brucella abortus specific antibodies reactive with the antigens used in the indirect hemolysis test. J Clin Microbiol 1981; 14: 415-26.

[75] Chappel R, Hayes J, Brain G, et al. A modified radioimmunoassay for antibodies against Brucella abortus. J Hyg 1982; 88:1-9.

[76] Chappel R, Hayes J, Rogerson B, et al. The serological response of cattle to vaccines against brucellosis, as measured by radioimmunoassay and other tests. J Hyg 1982; 88: 11-9.

[77] Hayes J, Chappel R. A comparison of the results of the brucellosis radioimmunoassay and other serological tests in experimentally infected cattle. J Hyg 1982; 88: 21-8.

[78] Sutherland SS, Le Cras D, Evans R. Comparison of the complement fixation test and the indirect hemolysis test for cattle vaccinated with Brucella abortus. J Clin Microbiol 1982; 16: 599603.

[79] Nielsen K, Heck F, Stiller J, et al. Interaction of specifically purified isotypes of bovine antibody to Brucella abortus in the haemolysis in gel test and enzyme linked immunosorbent assay. Res Vet Sci 1983; 35: 14-8.

[80] Ruckerbauer G, Garcia M, Rigby C, et al. An hemolysin-in-gel test for bovine brucellosis. Dev Biol Stand 1984; 56: 513-20.

[81] Myers D, Jones L, Varela-Diaz V. Studies of antigens for complement fixation and gel diffusion tests in the diagnosis of infections caused by Brucella ovis and other Brucella. Appl Microbiol 1972; 23: 894-902.

[82] Burgess G, Norris M. Evaluation of the cold complement fixation test for diagnosis of ovine brucellosis. Aust Vet J 1982; 57: 479-80.

[83] Searson J. Sensitivity and specificity of two microtitre complement fixation tests for the diagnosis of Brucella ovis infection in rams. Aust Vet J 1982; 36: 194-8.

[84] Marin C, de Bagues JM, Blasco J, et al. Comparison of three serological tests for Brucella ovis infection of rams using different antigenic extracts. Vet Rec 1989; 125: 504-8.

[85] Diaz R, Jones L, Leong D, et al. Surface antigens of smooth Brucellae. J Bacteriol 1968; 96: 893-900.

[86] Diaz R, Garatea P, Jones L, et al. Radial immunodiffusion test with Brucella polysaccharide antigen for differentiating infected from vaccinated cattle. J Clin Microbiol 1979; 10: 37-46.

[87] Asarta A. Erradicacion de la brucellosis en el ganado vacuno de Navarra. Actas del XII Congreso Nacional de Microbiologia. Sociedad Espanola Microbiologia. SEM Pamplona 1989; p. 371. 
[88] Jones L, Berman D, Moreno E, et al. Evaluation of a radial immunodiffusion with polysaccharide B antigen for diagnosis of bovine brucellosis. J Clin Microbiol 1980; 12: 753-8.

[89] Parratt D, Nielsen K, White RG. Radioimmunoassay of IgM, IgG and IgA Brucella antibodies. Lancet 1977; 1: 1075-8.

[90] Wilson D, Thornley M, Coombs R. A solid phase assay with radioactively labelled antibody for the detection of Brucella abortus. J Med Microbiol 1977; 10: 281-92.

[91] Levieux D. A solid phase radioimmunoassay for the determination of bacterial-specific antibodies within different immunoglobulin classes: application to bovine Brucella abortus antibodies. Ann Rech Vet 1978; 9: 523-30.

[92] Chappel R, Hayes J. Comparison of radioimmunoassay with complement fixation test and the indirect haemolysis test in the field diagnosis of brucellosis. J Hyg 1983; 90: 67-70.

[93] Lawman M, Thurmond $\mathrm{M}$, Reis $\mathrm{K}$, et al. Solid phase radioimmunoassay for detection of immunoglobulins against bovine Brucella abortus. Vet Immunol Immunopathol 1984; 6: 291-305.

[94] Lawman M, Ball D, Hoffmann E, et al. Production of Brucella abortus specific protein A reactive antibodies (IgG2) in infected and vaccinated cattle. Vet Microbiol 1986; 12: 43-53.

[95] Devlin J, Redington F, Stephenson M. A study using an isotope probe comparing immunoassay with serology detection of Brucella abortus antibody. Ir J Med Sci 1986; 155: 349-52.

[96] Hajdu S. Efficiency of the fluorescence method in the serological diagnosis of cattle and swine brucellosis. Arch Exp Vet Med 1966; 20: 293-306.

[97] Freibourg-Blanc A. Serologic diagnosis of brucellosis by the immunofluorescent technique. Med Press 1970; 78: 271-2.

[98] Olitzki A. Immunological methods in brucellosis research. 1. In vitro procedures. Bibl Microbiol 1970; 8: 1-249.

[99] Edwards J, Tannahill A, Bradstreet C. Comparison of the indirect fluorescent antibody test with agglutination, complement fixation and Coombs test for Brucella antibody. J Clin Pathol 1970; 23: $161-5$.

[100] Corbel MJ, Day CA. Assessment of fluorescent antibody absorption procedures for differentiation of the serological response to Yersinia enterocolitica serotype IX and Brucella abortus in cattle. Br Vet J 1973; 129: Ixvii-Ixxi.

[101] Henderson R, Hill D, Vickers A, Edwards J, Tillett H. Correlation between serological and immunofluorescence results in the investigation of brucellosis in veterinary surgeons. J Clin Pathol 1976; 29: 35-8.

[102] Fenske G. Value of antiglobulin test and indirect immunofluorescence test in the serological diagnosis of bovine brucellosis. Arch Exp Vet Med 1977; 31: 211-26.

[103] Sanchez Calle M, Alvarez Betes J, Juarez Fernandez C, Blasco RB. Diagnostic value of indirect immunofluorescence in brucellosis. Rev Clin Esp 1977; 147: 153-7.

[104] Raybould T, Chantler S. Serological differentiation between infected and vaccinated cattle by visual and quantitative immunofluorescence using Brucella abortus antigen couple Sepharose beads. J Immunol Methods 1979; 30: 37-46.

[105] Rodriguez NA, Diaz PJ, Santiago TR, et al. Usefulness of the indirect immunofluorescence test and the rose bengal test for the diagnosis of brucellosis. Rev Clin Esp 1984; 175: 27-31.

[106] Hall SM, Confer AW, Tabatabai L, et al. Detection of serum antibody to Brucella abortus in cattle using a quantitative fluorometric immunoassay. J Clin Microbiol 1984; 20: 1023-7.

[107] Hall SM, Confer AW. Comparison of TRACK XI fluorometric immunoassay system with other serologic tests for the detection of serum antibody to Brucella abortus in cattle. J Clin Microbiol 1987; 25: 350-4.

[108] Mirabet E, Torrogrosa R, Fraile M, et al. The indirect immunofluorescence test in the diagnosis of brucellosis. Rev Clin Esp 1988; 182: 18-21.

[109] Dhar R, Lastimoza J, Hira P. A modified indirect fluorescent antibody test for the diagnosis of brucellosis. Diagn Microbiol Infect Dis 1988; 11: 189-94.

[110] Colmenero J, Reguera J, Cabrera F, et al. Combined use of rose Bengal and indirect immunofluorescence in the diagnosis of brucellosis. Enferm Infecc Microbiol Clin 1989; 7: 316-20.

[111] Carlsson H, Hurvell B, Lindberg A. Enzyme linked immunosorbent assay (ELISA) for titration of antibodies against Brucella abortus and Yersinia enterocolitica. Acta Pathol Microbiol Scand 1976; 84C: $168-76$.

[112] Nielsen K, Gall D. Advances in the diagnosis of bovine brucellosis: use of enzyme immunoassays. Genet Eng Biotech 1994; 14: 25-39.

[113] Delgado S, Fernandez M, Carmeneres P. Evaluation of enzyme linked immunosorbent assay for the detection of sheep infected with Brucella melitensis. J Vet Diagn Invest 1995; 7: 206-9.

[114] Uzal F, Carrasco A, Echaide S, et al. Evaluation of an indirect ELISA for the diagnosis of bovine brucellosis. J Vet Diagn Invest 1995; 7: 473-5.

[115] Uzal F, Carrasco A, Nielsen K, et al. An indirect ELISA using a monoclonal IgG1 enzyme conjugate for the diagnosis of bovine brucellosis. Vet Microbiol 1996; 52: 175-80.

[116] Romero C, Pardo M, Grillo M, et al. Evaluation of PCR and indirect enzyme immunoassay on milk samples for the diagnosis of brucellosis in dairy cattle. J Clin Microbiol 1995; 33: 3198-200.

[117] Nielsen K, Smith P, Gall D, et al. Development and validation of an indirect enzyme immunoassay for detection of antibody to Brucella abortus in milk. Vet Microbiol 1996; 52: 165-73.

[118] Letesson J, Tibor A, van Eynde G, et al. Humoral immune response of Brucella infected cattle, sheep and goats to eight purified recombinant Brucella proteins in an indirect enzyme linked immunosorbent assay. Clin Diagn Lab Immunol 1997; 4: 556-64.

[119] Vanzini V, Aguirre N, Lugaresi C, et al. Evaluation of an indirect ELISA for the diagnosis of bovine brucellosis in milk and serum samples in Argentina. Prev Vet Med 1998; 36: 211-7.

[120] Vanzini V, Aguirre N, Valentini B, et al. Comparison of an indirect ELISA with the Brucella milk ring test for the detection of antibodies to Brucella abortus in bulk milk samples. Vet Microbiol 2001; 82: 55-60.

[121] Alonso-Urmeneta B, Marin C, Aragon V, et al. Evaluation of lipopolysaccharides and polysaccharides of different epitopic structures in the indirect enzyme linked immunosorbent assay for the diagnosis of brucellosis in small ruminants and cattle. Clin Diagn Lab Immunol 1998; 5: 749-54.

[122] Jacques I, Olivier-Bernardin V, Dubray G. Efficacy of ELISA compared to conventional tests (RBPT and CFT) for the diagnosis of Brucella melitensis infection in sheep. Vet Microbiol 1998; 64: 61-73.

[123] Marin C, Moreno E, Moryion I, et al. Performance of competitive and indirect enzyme linked immunosorbent assays, gel immunoprecipitation with native hapten and standard serological tests in the diagnosis of sheep brucellosis. Clin Diagn Lab Immunol 1999; 6: 269-72.

[124] Samartino L, Gall D, Gregoret R, et al. Validation of enzyme linked immunosorbent assays for the diagnosis of bovine brucellosis. Vet Microbiol 1999; 70: 193-200.

[125] Abalos P, Daffner J, Pinochet L. Evaluation of three Brucella soluble antigens used in an indirect ELISA to discriminate S19 vaccinated from naturally infected cattle. Vet Microbiol 2000; 71: 161-7.

[126] Paulo PS, Vigliocco A, Ramondino R, et al. Evaluation of primary binding assays for the presumptive serodiagnosis of swine brucellosis in Argentina. Clin Diagn Lab Immunol 2000; 7: 828-31.

[127] Guarino A, Fusco G, Di Matteo A, et al. Indirect ELISA for the diagnosis of brucellosis in water buffaloes (Bubalus bubalis) in Italy. Vet Rec 2001; 149: 88-90.

[128] Renukaradhya G, Isloor S, Crowther J, et al. Development and field validation of an avidin-biotin enzyme linked immunosorbent assay kit for bovine brucellosis. Rev Sci Tech 2001; 20: 749-56.

[129] Paweska J, Potts A, Harris H, et al. Validation of an indirect enzyme linked immunosorbent assay for detection of antibody against Brucella abortus in cattle using an automated ELISA workstation. Onderstepoort J Vet Res 2002; 69: 61-77.

[130] Ferreira A, Cardoso R, Travassos Dias I, et al. Evaluation of a modified Rose Bengal test and an indirect enzyme linked immunosorbent assay for the diagnosis of Brucella melitensis in sheep. Vet Res 2003; 34: 297-305.

[131] Cassataro J, Pasquevich K, Bruno L, et al. Antibody reactivity to OMP31 from Brucella melitensis in human and animal infections by smooth and rough Brucellae. Clin Diagn Lab Immunol 2004; 11: 111-4.

[132] Estein S, Cheves $\mathrm{P}$, Fiorentino $\mathrm{M}$, et al. Immunogenicity of recombinant Omp31 from Brucella melitensis in rams and serum 
bacteriocidal activity against $B$. ovis. Vet Microbiol 2004; 102: 203-13.

[133] Chand P, Sadana J, Malhotra A, et al. Indirect ELISA for detection of antibodies to Brucella melitensis in sheep milk. Vet Rec 2004; 155: 639-91.

[134] Nielsen K, Smith P, Widdison J, et al. Serological relationship between cattle exposed to Brucella abortus, Yersinia enterocolitica O:9 and Eschericia coli O157:H7. Vet Microbiol 2004; 100: 25-30.

[135] Nielsen K, Smith P, Yu W, et al. Enzyme immunoassay for the diagnosis of brucellosis: chimeric Protein A-Protein G as a common enzyme labelled detection reagent for sera from different animal species. Vet Microbiol 2004; 101: 123-9.

[136] Nielsen K, Gall D, Smith P, et al. Comparison of serological tests for the detection of ovine and caprine antibody to Brucella melitensis. Rev Sci Tech 2004; 23: 979-87.

[137] Funk N, Tabatabai L, Elzer P, et al. Indirect enzyme linked immunosorbent assay for detection of Brucella melitensis specific antibodies in goat milk. J Clin Microbiol 2005; 43: 721-5.

[138] Nielsen K, Smith P, Yu W, et al. Towards a single screening test for brucellosis. Rev Sci Tech 2005; 24: 1027-37.

[139] Mainar-Jaime R, Munoz P, de Miguel M, et al. Specificity dependence between serological tests for diagnosing bovine brucellosis in Brucella free farms showing false positive serological reactions due to Yersinia enterocolitica O:9. Can Vet J 2005; 46: 913-6.

[140] Nielsen K, Smith P, Yu W, et al. Serological discrimination by indirect enzyme immunoassay between the antibody response to Brucella sp. and Yersinia enterocolitica $0: 9$ in cattle and pigs. Vet Immunol Immunopathol 2006; 109: 69-78.

[141] Gall D, Nielsen K, Nicola A, et al. A proficiency testing method for detecting antibodies against Brucella abortus in quantitative and qualitative serological tests. Rev Sci Tech 2008; 27: 819-28.

[142] Barrio M, Grillo M, Munoz P, et al. Rough mutants defective in core and $\mathrm{O}$-polysaccharide synthesis and export induce antibodies reacting in an indirect ELISA with smooth lipopolysaccahride and are less effective than Rev1 vaccine against Brucella melitensis infection in sheep. Vaccine 2009; 27: 1741-9.

[143] Rahaley RS, Dennis SM, Smeltzer MS. Comparison of enzyme linked immunosorbent assay and complement fixation test for detection of Brucella ovis antibodies in sheep. Vet Rec 1983; 113: 467-70.

[144] Ris D, Hamel K, Long D. Comparison of an enzyme linked immunosorbent assay (ELISA) with the cold complement fixation test for the serodiagnosis of Brucella ovis infection. $\mathrm{N} \mathrm{Z} \mathrm{Vet} \mathrm{J}$ 1984; 32: 18-20.

[145] Worthington R, Weddell W, Penrose M. A comparison of three serological tests for the diagnosis of Brucella ovis infection in rams. N Z Vet J 1984; 32: 58-60.

[146] Ficapal A, Alonso-Urmeneta B, Velasco J, et al. Diagnosis of Brucella ovis infection in rams with an ELISA using protein $\mathrm{G}$ as conjugate. Vet Rec 1995; 137: 145-7.

[147] Vigliocco A, Silva P, Mestre J, et al. Development and validation of an indirect enzyme immunoassay for detection of ovine antibody to Brucella ovis. Vet Microbiol 1997; 54: 357-68.

[148] Lucero N, Escobar G, Ayala S, et al. Sensitivity and specificity of an indirect enzyme linked immunoassay for the diagnosis of Brucella canis infection in dogs. J Med Microbiol 2002; 51: 65660.

[149] Lucero N, Escobar G, Ayala S, et al. Diagnosis of human brucellosis caused by Brucella canis. J Med Microbiol 2005; 54 : 457-61.

[150] Ebani VV, Cerri D, Fratini F, et al. Serological diagnosis of brucellosis caused by Brucella canis. New Microbiol 2003; 26: 6573.

[151] Lopez G, Ayala S, Escobar G, et al. Use of Brucella canis antigen for detection of ovine serum antibodies against Brucella ovis. Vet Microbiol 2004; 105: 181-7.

[152] Lopez G, Escobar G, Ayala S, et al. Detection of antibodies to Brucella ovis in sheep milk using $B$. ovis and B. canis antigen. Vet Immunol 2006; 116: 232-8.

[153] Nielsen K, Smith P, Conde S, et al. Rough lipopolysaccharide of Brucella abortus for serological detection of B. ovis, B. canis and $B$. abortus RB51 exposure using indirect enzyme immunoassay and fluorescence polarization assay. J Immunoassay Immunochem 2004; 25: 171-82.
[154] Barrouin-Melo S, Poester FP, Ribeiro M, et al. Diagnosis of canine brucellosis by ELISA using an antigen obtained from wild Brucella canis. Res Vet Sci 2007; 83: 340-6.

[155] Robles C, Nielsen K, Gall D, et al. An indirect enzyme linked immunoassay for detection of antibodies against Brucella abortus RB51 in vaccinated heifers. Vet Immunol Immunopathol 2009; 127: $153-5$.

[156] Limet JN, Cloeckaert A, Bezard G, et al. Antibody response to the $89 \mathrm{kDa}$ outer membrane protein of Brucella in bovine brucellosis. J Med Microbiol 1993; 30: 403-7.

[157] Baldi P, Wanke M, Loza M, et al. Brucella abortus cytoplasmic proteins used as antigens in an ELISA potentially useful for the diagnosis of canine brucellosis. Vet Microbiol 1994; 41: 127-34.

[158] Baldi P, Wanke M, Loza M, et al. Diagnosis of canine brucellosis by detection of serum antibodies against an $18 \mathrm{kDa}$ cytoplasmic protein of Brucella sp. Vet Microbiol 1997; 57: 273-81.

[159] Bowden R, Cloeckaert A, Zygmunt M, et al. Evaluation of immunogenicity and protective activity in BALB/c mice of the 25 $\mathrm{kDa}$ major outer membrane protein of Brucella melitensis (Omp 25) expressed in Eschericia coli. J Med Microbiol 1998; 47: 39-48.

[160] Kittelberger R, Diack D, Vizcaino N, et al. Characterization of an immuno-dominant antigen in Brucella ovis and evaluation of its use in enzyme linked immunosorbent assay. Vet Microbiol 1998; 59: 213-27.

[161] Cloeckaert A, Baucheron S, Vizcaino N, et al. Use of recombinant BP26 protein in serological diagnosis of Brucella melitensis in sheep. Clin Diagn Lab Immunol 2001; 8: 722-75.

[162] Delpino M, Cassataro J, Fossati C, et al. Antibodies to CP24 protein of Brucella melitensis lack diagnostic usefulness in ovine brucellosis. Vet Microbiol 2003; 93: 101-7.

[163] Zygmunt M, Baucheron S, Vizcaino N, et al. Single step and evaluation of recombinant BP26 protein for serological diagnosis of Brucella ovis infection in rams. Vet Microbiol 2002; 87: 213-20.

[164] Cassataro J, Pasquevich K, Bruno L, et al. Antibody reactivity to Omp31 from Brucella melitensis in human and animal infections by smooth and rough Brucellae. Clin Diagn Lab Immunol 2004; 11: 111-4.

[165] Mahajan N, Kulshreshtha R, Malik G, et al. Immunogenicity of major cell surface proteins of Brucella melitensis Rev 1. Vet Res Commun 2005; 29: 189-99.

[166] Snyder M, McMahon P, Workman E. In: Nielsen KH, Duncan JR Eds. An automated fluorescence based brucellosis test system with a proven track record. Boca Raton: CRC Press 1990; pp. 237-82.

[167] Nicoletti P, Tanya V. Comparison of enzyme labelled immunosorbent assay and particle concentration fluorescence immunoassay with standard serologic methods and bacterial culture for detection of Brucella sp. infected cows in herds with brucellosis. J Am Vet Med Assoc 1993; 202: 1975-7.

[168] Rylatt D, Wyatt D, Bundesen P. A competitive enzyme immunoassay for the detection of bovine antibodies to Brucella abortus using monoclonal antibodies. Vet Immunol Immunopathol 1985; 8: 261-71.

[169] Sutherland S. An enzyme linked immunosorbent assay for detection of Brucella abortus in cattle using monoclonal antibodies. Aust Vet J 1985; 62: 264-72.

[170] Sutherland S, den Hollander. Comparison of an enzyme linked immunosorbent assay using monoclonal antibodies and a complement fixation test for cattle vaccinated and infected with Brucella abortus. Vet Microbiol 1986; 12: 55-64.

[171] Nielsen K, Cherwonogrodsky J, Duncan R, et al. Enzyme immunoassay for the differentiation of antibody response of Brucella abortus infected and vaccinated cattle. Am J Vet Res 1989; 50: 5-9.

[172] Chin J, Daniels J, Bundesen P. Bovine brucellosis: evaluation of field sera by a competitive and superimposable ELISA utilizing a monoclonal antibody against Brucella abortus lipopolysaccharide. Vet Immunol Immunopathol 1989; 20: 109-18.

[173] Yong WK, Edwards LD, Searson JE. Evaluation of three LPSspecific monoclonal antibodies for the diagnosis of bovine brucellosis. Res Vet Sci 1989; 46: 413-5.

[174] MacMillan A, Greiser-Wilde I, Moenning V, et al. A competitive enzyme immunoassay for brucellosis diagnosis. Dtsch Tierarztl Wchnschr 1990; 97: 83-5.

[175] Cloeckaert A, Kerkhofs P, Limet J. Antibody response to Brucella outer membrane proteins in bovine brucellosis: immunoblot 
analysis and competitive enzyme linked immunosorbent assay using monoclonal antibodies. J Clin Microbiol 1992; 30: 3168-74.

[176] Gall D, Nielsen K. Improvements to the competitive ELISA for detection of antibodies to Brucella abortus in cattle sera. J Immunoassay 1994; 15: 277-91.

[177] Nielsen K, Kelly L, Gall D, et al. Improved CELISA for the diagnosis of bovine brucellosis. Vet Immunol Immunopathol 1995; 48: 285-91.

[178] Uzal F, Carrasco A, Nielsen K. Evaluation of a competitive ELISA for the diagnosis of bovine brucellosis. Vet Res Commun 1996; 20 : 421-6.

[179] Weynants V, Gilson D, Cloeckaert A, et al. Characterization of a monoclonal antibody specific for Brucellla smooth lipopolysaccharide and development of a competitive enzyme linked immunosorbent assay to improve the serological diagnosis of brucellosis. Clin Diagn Lab Immunol 1996; 3: 309-14.

[180] Debbarh H, Zygmunt M, Dubray G, et al. Competitive enzyme linked immunosorbent assay using monoclonal antibodies to the Brucella melitensis BP26 protein to evaluate antibody responses in infected and $B$. melitensis Rev 1 vaccinated sheep. Vet Microbiol 1996; 53: 325-37.

[181] Gall D, Colling A, Marino O, et al. Enzyme immunoassays for serological diagnosis of bovine brucellosis: a trial in Latin America. Clin Diagn Lab Immunol 1998; 5: 654-61.

[182] Marin C, Moreno E, Moriyon I, et al. Performance of competitive and indirect enzyme linked immunosorbent assays, gel immunoprecipitation with native hapten polysaccharide and standard serological test in the diagnosis of sheep brucellosis. Clin Diagn Lab Immunol 1999; 6: 269-72.

[183] Lucero N, Foglia L, Alaya S, et al. Competitive enzyme immunoassay for diagnosis of human brucellosis. J Clin Microbiol 1999; 37: 3245-8

[184] Biancifiori F, Garrido F, Nielsen K, et al. Assessment of a monoclonal antibody based competitive enzyme linked immunosorbent assay (cELISA) for diagnosis of brucellosis in infected and Rev 1 vaccinated sheep and goats. New Microbiol 2000; 23: 399-407.

[185] McGiven J, Tucker J, Perrett L, et al. Validation of FPA and cELISA for the detection of antibodies to Brucella abortus in cattle sera and comparison to SAT, CFT and iELISA. J Immunol Method 2003; 278: 171-8

[186] Van Houten C, Lee Belden E, Kreeger T, et al. Validation of a Brucella abortus competitive enzyme linked immunosorbent assay for use in Rocky Mountain elk (Cervus elaphus nelsoni). J Wildl Dis 2003; 39: 316-22.

[187] Duran-Ferrer M, Leon L, Nielsen K, et al. Antibody response and antigen specific gamma interferon profiles of vaccinated and unvaccinated pregnant sheep experimentally infected with Brucella melitensis. Vet Microbiol 2004; 100: 219-31.

[188] Nielsen K, Gall D, Smith P, et al. Comparison of serological tests for detection of ovine and caprine antibody to Brucella melitensis. Rev Sci Tech Off Int Epiz 2004; 23: 979-87.

[189] Portani O, Tittarelli M, Di Febo T, et al. Development and validation of a competitive ELISA for the serological diagnosis of ovine, caprine and bovine brucellosis. J Vet Med B Infect Dis Vet Public Health 2006; 53: 494-8.

[190] Nielsen K, Smith P, Yu WL, et al. Second generation competitive enzyme immunoassay for detection of bovine antibody to Brucella abortus. Vet Microbiol 2007; 124: 173-7.

[191] Nielsen K, Smith P, Yu WL, et al. Validation of a second generation competitive enzyme immunoassay (CELISA) for the diagnosis of brucellosis in various species of domestic animals. Vet Immunol Immunopathol 2008; 125: 246-50.

[192] Muma JB, Toft N, Oloya J, et al. Evaluation of three serological tests for brucellosis in naturally infected cattle using latent class analysis. Vet Microbiol 2007; 125: 187-92.

[193] Thompson I, McGiven J, Sawyer J, et al. Competitive electrochemiluminescence wash and no-wash immunoassays for detection of serum antibodies to smooth Brucella strains. Clin Vaccine Immunol 2009; 16: 765-71.

[194] Nielsen K, Gall D, Jolley M, et al. A homogeneous fluorescence polarization assay for detection of antibody to Brucella abortus. J Immunol Method 1996; 195: 161-8.

[195] Samartino L, Gregoret R, Gall D, et al. Fluorescence polarization assay: application to the diagnosis of bovine brucellosis in Argentina. J Immunoassay 1999; 20: 115-20.
[196] Dajer A, Luna-Martinez E, Zapata D, et al. Evaluation of a fluorescence polarization assay for the diagnosis of bovine brucellosis in Mexico. Prev Vet Med 1999; 14: 67-73.

[197] Nielsen K, Gall D, Smith P, et al. Validation of the fluorescence polarization assay as a serological test for the presumptive diagnosis of porcine brucellosis. Vet Microbiol 1999; 68: 245-53.

[198] Gall D, Nielsen K, Forbes L, et al. Validation of the fluorescence polarization assay and comparison to other serological assays for the detection of serum antibody to Brucella abortus in bison. J Wildl Dis 2000; 36: 469-76.

[199] Nielsen K, Lin M, Gall D, et al. In: Ngo TT, Ed. Fluorescence polarization immunoassay: detection of antibody to Brucella abortus. London: Academic Press 2000; pp. 71-6.

[200] Nielsen K, Smith P, Gall D, et al. Validation of the fluorescence polarization assay for detection of milk antibody to Brucella abortus. J Immunoassay Immunochem 2001; 22: 203-11.

[201] Nielsen K, Gall D, Bermudez R, et al. Field trial of brucellosis fluorescence polarization assay. J Immunoassay Immunochem 2002; $23: 307-16$.

[202] Lucero N, Escobar G, Ayala S, et al. Fluorescence polarization assay for the diagnosis of human brucellosis. J Med Microbiol 2003; 52: 883-7.

[203] Nielsen K, Gall D, Smith P, et al. Evaluation of serological tests for the detection of caprine antibody to Brucella melitensis. Small Rumin Res 2005; 56: 253-8.

[204] Bahn P, Nockler K. Validation of the fluorescence polarization assay (FPA) for the serological diagnosis of brucellosis. Berl Tierarztl Wochenschr 2005; 118: 372-6.

[205] Minas A, Stournara A, Minas M, et al. Validation of fluorescence polarization assay (FPA) and comparison with other tests used for diagnosis of B. melitensis infection in sheep. Vet Microbiol 2005; 111:211-21.

[206] Nielsen O, Nielsen K, Braun R, et al. A comparison of four serological assays for screening for Brucella exposure in Hawaiian monk seals. J Wildl Dis 2005; 41: 126-33.

[207] Ramirez-Pfeiffer C, Nielsen K, Marin-Ricalde F, et al. Comparison of fluorescence polarization assay with card and complement fixation tests for the diagnosis of goat brucellosis in a high prevalence area. Vet Immunol Immunopathol 2006; 110: 121-7.

[208] Stournara A, Minas A, Bourtzi-Chatzopoulou E, et al. Assessment of serological responses of young and adult sheep to conjunctival vaccination with Rev 1 vaccine by fluorescence polarization assay (FPA) and other serological tests for B. melitensis. Vet Microbiol 2007; 119: 53-64.

[209] Ramirez-Pfeiffer C, Nielsen K, Smith P, et al. Application of the fluorescence polarization assay for detection of caprine antibodies to Brucella melitensis in areas of high prevalence and widespread vaccination. Clin Vaccine Immunol 2007; 14: 299-303.

[210] Konstantinidis A, Minas A, Pournaras S, et al. Evaluation and comparison of fluorescence polarization assay with three of the currently used serological tests in the diagnosis of human brucellosis. Eur J Clin Microbiol Infect Dis 2007; 26: 715-21.

[211] Ramirez-Pfeiffer C, Diaz-Aparicio E, Rodriguez-Padilla C, et al. Improved performance of Brucella melitensis native hapten over Brucella abortus OPS tracer on goat antibody detection by the fluorescence polarization assay. Vet Immunol Immunopathol 2008; 123: 223-9.

[212] Ramirez-Pfeiffer C, Diaz-Aparicio E, Gomez-Flores R, et al. Use of the Brucella melitensis native hapten to diagnose brucellosis in goats by a simple, rapid and specific fluorescence polarization assay. Clin Vaccine Immunol 2008; 15: 211-5.

[213] Montagnaro S, Longo M, Mallardo K, et al. Evaluation of fluorescence polarization assay for the detection of serum antibodies to Brucella abortus in water buffalo (Bubalus bubalis). Vet Immunol Immunopathol 2008; 125: 135-42.

[214] Silva M, Cruz H, Rossetti O, et al. Development of an optical immunosensor based on the fluorescent of cyanini-5 for veterinarian diagnostics. Biotechnol Lett 2004; 26: 993-7.

[215] McGiven J, Sawyer J, Perrett L, et al. A new homogeneous assay for high throughput serological diagnosis of brucellosis in ruminants. J Immunol Method 2008; 337: 7-15.

[216] Smits H, Abdoel T, Solera J, et al. Immunochromatographic Brucella specific immunoglobulin $\mathrm{M}$ and $\mathrm{G}$ lateral flow assays for rapid serodiagnosis of human brucellosis. Clin Diagn Lab Immunol 2003; 10: 1141-6. 
[217] Kim J, Lee Y, Han M, et al. Evaluation of immunochromatographic assay for serodiagnosis of Brucella canis. J Vet Med Sci 2007; 69: 1103-7.

[218] Abdoel T, Dias I, Cardoso R, et al. Simple and rapid field test for brucellosis in livestock. Vet Microbiol 2008; 130: 312.

[219] Bronsvoort B, Koterwas B, Land F, et al. Comparison of a flow assay for brucellosis antibodies with the reference cELISA test in West African Bos indicus. PLoS ONE 2009; 4: e5221.

[220] George LW, Carmichael LE. Development of a rose bengal stained antigen for the rapid diagnosis of Brucella canis infection. Cornell Vet 1987; 68: 530-43.

[221] Badakhsh F, Carmichael L, Douglass J. Improved rapid slide agglutination test for presumptive diagnosis of canine brucellosis. Clin Microbiol 1982; 15: 286-9.

[222] Carmichael L, Joubert J. A rapid slide agglutination test for the serodiagnosis of Brucella canis that employs a variant (M) organism as antigen. Cornell Vet 1987; 77: 3-12.

[223] Reid L, Soares R, Vasconcellos S, et al. Comparison of agar gel immunodiffusion test, rapid slide agglutination test, microbial culture and PCR for the diagnosis of canine brucellosis. Res Vet Sci 2009; 86: 22-7.

[224] Kimura M, Imaoka K, Suzuki M, et al. Evaluation of a microagglutination test (MAT) for serological diagnosis of canine brucellosis. J Vet Med Sci 2008; 70: 707-9.

[225] Behan K, Kelin G. Reduction of Brucella species and Francisella tularensis cross-reacting agglutinins by dithiothreitol. J Clin Microbiol 1982; 16: 756-7.

[226] Rossetti O, Arese A, Boschiroli M, et al. Cloning of Brucella abortus gene and characterization of expressed 26-kilodalton periplasmic protein: potential use for diagnosis. J Clin Microbiol 1996; 34: 165-9.

[227] Seco-Mediavilla P, Verger J, Grayon M, et al. Epitope mapping of the Brucella melitensis BP26 immunogenic protein: usefulness for diagnosis of sheep brucellosis. Clin Diagn Lab Immunol 2003; 10: 647-51.

[228] Cloeckaert A, Jacques I, Grillo M, et al. Development and evaluation as vaccines in mice of Brucella melitensis Rev 1 single and double deletion mutants of the $b p 26$ and omp 31 genes coding for antigens of diagnostic significance in ovine brucellosis. Vaccine 2004; 22 : 2827-35.
[229] Nielsen K, Smith P, Yu W, et al. Salmonella enterica Serotype Urbana interferes with brucellosis serology. J Immunoassay Immunochem 2007; 28: 289-96.

[230] Nielsen K, Smith P, Widdison J, et al. Serological relationship between cattle exposed to Brucella abortus, Yersinia enterocolitica O:9 and Escherichia coli O157:H7. Vet Microbiol 2004; 100: 2530 .

[231] Munoz P, Marin C, Monreal D, et al. Efficacy of several serological tests and antigens for diagnosis of bovine brucellosis in the presence of false-positive results due to Yersinia enterocolitica O:9. Clin Diagn Lab Immunol 2005; 12: 141-51.

[232] Staak C, Draeger A, Bahn P, et al. Contribution to the differentiation of cross-reacting antibodies in brucellosis serology1. Reactions with various Yersinia serotypes and antibody avidity. Berl Munch Tierarztl Wochenschr 2000; 113: 361-7.

[233] Bercovich Z, Haagsma J, van Lipzig J, et al. Specificity of the skin delayed-type hypersensitivity test in brucellosis free cattle tested with a Brucella allergen. Zentralbl Veterinarmed B 1993; 40: 5828.

[234] Saegerman C, Vo T, De Waele L, et al. Diagnosis of bovine brucellosis by skin test: conditions for the test and evaluation of its performance. Vet Rec 1999; 145: 214-8.

[235] Bercovich Z. The use of skin delayed-type hypersensitivity as an adjunct test to diagnose brucellosis in cattle: a review. Vet Q 2000; 22: $123-30$.

[236] Chukwu CC. Differentiation of Brucella abortus and Yersinia enterocolitica serotype 0:9 infections in cattle: the use of specific lymphocyte transformation and brucellin skin tests. Vet Q 1987; 9: $134-42$.

[237] Kittelberger R, Reichel M, Joyce $M$, et al. Serological crossreactivity between Brucella abortus and Yersinia enterocolitica O:9. III. Specificity of the in vitro antigen specific gamma interferon test for bovine brucellosis diagnosis in experimentally Yersinia enterocolitica 0:9 infected cattle. Vet Microbiol 1997; 57: 361-71.

[238] Riber U, Jungersen G. Cell mediated immune responses differentiate infections with Brucella suis from serotype 0:9 in pigs. Vet Immunol Immunopathol 2007; 116: 13-25.

[239] Thirwall R, Commander N, Brew S, et al. Improving the specificity of immunodiagnosis for porcine brucellosis. Vet Res Commun 2008; 32: 209-13.

(C) Poester et al.; Licensee Bentham Open.

This is an open access article licensed under the terms of the Creative Commons Attribution Non-Commercial License (http://creativecommons.org/licenses/by-nc/ 3.0/) which permits unrestricted, non-commercial use, distribution and reproduction in any medium, provided the work is properly cited. 